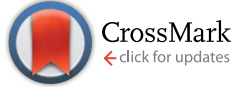

Cite this: J. Mater. Chem. A, 2016, 4, 7053

Received 23rd December 2015 Accepted 20th March 2016

DOI: $10.1039 / c 5 t a 10568 d$

www.rsc.org/MaterialsA

\title{
Inexpensive colloidal SnSb nanoalloys as efficient anode materials for lithium- and sodium-ion batteries $\uparrow$
}

\begin{abstract}
Marc Walter, ${ }^{\mathrm{ab}}$ Simon Doswald ${ }^{\mathrm{ab}}$ and Maksym V. Kovalenko*ab
The quest for higher energy densities of lithium-ion batteries (LIBs) and emerging sodium-ion analogues (SIBs) has motivated an intense research effort toward novel electrode materials. We report a simple and inexpensive colloidal synthesis of SnSb nanocrystals (NCS) and demonstrate their utility as lithium- and sodium-ion anode materials. In particular, SnSb NC Li-ion anodes deliver capacities of $\sim 890 \mathrm{~mA} \mathrm{~h} \mathrm{~g}^{-1}$ for 100 cycles at a current density of $200 \mathrm{~mA} \mathrm{~g}^{-1}$ and show excellent rate capability, reaching $90 \%$ and $80 \%$ of the theoretical capacity at current densities of 1000 and $5000 \mathrm{~mA} \mathrm{~g}^{-1}$, respectively. Similarly, SnSb NCs show also outstanding Na-ion storage properties with only 5\% capacity loss over 100 cycles at a rate of $5000 \mathrm{~mA} \mathrm{~g}^{-1}$. Full-cells can be constructed with SnSb anodes and state-of-the-art cathodes, achieving anodic capacities of 600 and $400 \mathrm{~mA} \mathrm{~h} \mathrm{~g}^{-1}$ with an average discharge voltage of 3.0 and $2.7 \mathrm{~V}$ for lithium- and sodium-ions, respectively.
\end{abstract}

\section{Introduction}

Lithium-ion batteries (LIBs) with higher energy and power densities are actively sought to increase the competitiveness and widespread deployment of electric cars and stationary energy storage units, and for enabling new portable electronic devices. ${ }^{1,2}$ Great hopes have been extended to conceptually similar sodium-ion batteries (SIBs) $)^{3-5}$ due to the much greater natural abundance of $\mathrm{Na}$ and the possibility of replacing copper anode current collectors with aluminum foils. The eventual success of SIBs will require this technology to have the same energy density as LIBs.

The energy density of a battery is primarily determined by the charge storage capacity of the electrode materials and the overall voltage of the battery. In this regard, SIBs face a critical challenge: a lack of efficient anode materials. For instance, graphite, the commercialized anode material for LIBs, shows only negligible Na-ion capacity, ${ }^{6,7}$ causing a recent surge of research on Na-ion anode materials. ${ }^{8-25}$ Certain metals and metalloids that alloy with $\mathrm{Na}$ and $\mathrm{Li}$ are especially promising, such as $\mathrm{Sb}$ and $\mathrm{Sn}$ which both show 2-3 times higher gravimetric and volumetric energy densities than that of graphite (e.g., $992 \mathrm{~mA} \mathrm{~h} \mathrm{~g}^{-1}$ or $\sim 7300 \mathrm{~mA} \mathrm{~h} \mathrm{~cm}{ }^{-3}$ for the reversible

\footnotetext{
${ }^{a}$ Department of Chemistry and Applied Biosciences, ETH Zürich - Swiss Federal Institute of Technology Zürich, Vladimir Prelog Weg 1, 8093 Zürich, Switzerland. E-mail: mvkovalenko@ethz.ch

${ }^{b}$ Empa-Swiss Federal Laboratories for Materials Science and Technology, Laboratory for Thin Films and Photovoltaics, Überlandstrasse 129, 8600 Dübendorf, Switzerland $\dagger$ Electronic supplementary information (ESI) available. See DOI: $10.1039 / \mathrm{c} 5$ ta10568d
}

formation of $\mathrm{Li}_{4.4} \mathrm{Sn}$ ). However, alloying leads to a much more intense reconstruction of the host material, as compared to intercalation. Such anode materials undergo massive volume changes of $120-300 \%$ upon lithiation (even greater for Na-ions), causing fast capacity fading due the formation of cracks, loss of electrical contact and eventual disintegration of the electrode. Nanostructuring of the electrode material has been demonstrated to efficiently mitigate the effects of mechanical stress on many systems. ${ }^{26-37}$ In this work, we focus on $\mathrm{SnSb}$ as a promising anode material and present a facile and inexpensive solution-based synthesis of nanocrystals (NCs) of this compound with a mean size of $10-30 \mathrm{~nm}$, and demonstrate their efficient performance for Na-ion and Li-ion storage.

The choice of the SnSb system stems from several synergistic effects between $\mathrm{Sn}$ and Sb. First, both components of this alloy contribute to its high theoretical capacity of $824 \mathrm{~mA} \mathrm{~h} \mathrm{~g}^{-1}:^{38}$

$$
\begin{gathered}
\mathrm{SnSb}+x \mathrm{Li}^{+}+x \mathrm{e}^{-} \rightarrow \mathrm{Li}_{x} \mathrm{SnSb}(x=0-1.6) \\
\mathrm{Li}_{1.6} \mathrm{SnSb}+1.4 \mathrm{Li}^{+}+1.4 \mathrm{e}^{-} \rightarrow \mathrm{Li}_{3} \mathrm{Sb}+\mathrm{Sn} \\
\mathrm{Sn}+4.4 \mathrm{Li}^{+}+4.4 \mathrm{e}^{-} \rightarrow \mathrm{Li}_{4.4} \mathrm{Sn}
\end{gathered}
$$

Similarly, the theoretical maximum capacity for Na-ion storage in $\mathrm{SnSb}$ is $752 \mathrm{~mA} \mathrm{~h} \mathrm{~g}^{-1}$ based on the formation of $\mathrm{Na}_{3} \mathrm{Sb}$ and $\mathrm{Na}_{3.75} \mathrm{Sn}$; however, the exact mechanism of this reaction is not fully understood, except that it does not occur in analogy to $\mathrm{Li}$ and is not a mere combination of the separate processes taking place for $\mathrm{Sb}$ and $\mathrm{Sn}^{39}$

Secondly, alloying/dealloying reactions of $\mathrm{Sn}$ and $\mathrm{Sb}$ occur at different potentials, which smoothens the mechanical stress 
somewhat. Finally, $\mathrm{Sn}$ and $\mathrm{Sb}$ are at least as inexpensive as common cathode materials comprising transition metals (e.g. Co and V). Notable examples of SnSb-based anode materials for both $\mathrm{Li}$ - and Na-ion storage are monodisperse $\mathrm{SnSb} \mathrm{NCs},{ }^{40}$ $\mathrm{SnSb}-\mathrm{C}$ nanofibers, ${ }^{32} \mathrm{CNT}-\mathrm{Sn}-\mathrm{Sb}$ nanorods, ${ }^{41}$ and $\mathrm{SnSb}-\mathrm{C}$ composites. ${ }^{18,42-44}$

A specific goal of this study was to develop a new synthesis route to $\mathrm{SnSb} \mathrm{NCs}$ that is orders of magnitude cheaper than that in our previous study. ${ }^{40}$ That previous synthesis route involved the use of expensive, air-sensitive organic and coordination compounds (alkylamides as precursors, alkylamines as solvents, long-chain surfactants and reducing agents), as well as multiple steps of washing and removal of surface capping ligands, with a very low overall atomic economy. ${ }^{40}$ Here, we present a surfactant-free synthesis that is at least 1000 times cheaper, by utilizing metal chlorides as precursors and $\mathrm{NaBH}_{4}$ as a reducing agent, and which does not require any postsynthetic purification other than rinsing in water. We demonstrate that these $\mathrm{SnSb}$ NCs exhibit electrochemical performance which is the same as or better than that of the "expensive" NCs from the previous study. ${ }^{40}$ We also present results from full-cell experiments. Under anode-limiting operation, $\mathrm{SnSb}$ NCs retain Li-ion capacities of $600 \mathrm{~mA} \mathrm{~h} \mathrm{~g}^{-1}$ at an average voltage of $3.0 \mathrm{~V}$ when paired with a $\mathrm{LiCoO}_{2}$ cathode, and a Na-ion capacity of $400 \mathrm{~mA} \mathrm{~h} \mathrm{~g}{ }^{-1}$ at an average voltage of $2.7 \mathrm{~V}$ when paired with a $\mathrm{Na}_{1.5} \mathrm{VPO}_{4.8} \mathrm{~F}_{0.7}$ cathode.

\section{Experimental}

\section{Synthesis of SnSb NCs}

A solution of $\mathrm{NaBH}_{4}$ (32 mmol, 98\%, ABCR) in anhydrous 1-methyl-2-pyrrolidone (NMP, $17 \mathrm{~mL}, 99.5 \%$, Fisher BioReagents) was heated to $60{ }^{\circ} \mathrm{C}$ under nitrogen. Upon reaching $60{ }^{\circ} \mathrm{C}$, a solution of $\mathrm{SnCl}_{2}(1 \mathrm{mmol}, \geq 99 \%$, Alfa Aesar $)$ dissolved in anhydrous NMP $(1.5 \mathrm{~mL})$ was injected, followed immediately by the injection of $\mathrm{SbCl}_{3}(1 \mathrm{mmol}, 99 \%, \mathrm{ABCR})$ and cooling down to room temperature using a water-ice bath. The resulting black precipitate was separated from the solution by centrifugation and washed three times with water $(30 \mathrm{~mL})$ to remove side products such as $\mathrm{NaCl}$ or borates. After drying under vacuum at room temperature a fine black powder was obtained with a yield of $\sim 0.2 \mathrm{~g}(83 \%)$.

\section{Synthesis of bulk SnSb}

Micrometer-sized SnSb particles were synthesized by heating a mixture of Sn (1 mmol, 99.8\%, Sigma-Aldrich) and Sb powder (1 mmol, 99.5\%, Alfa Aesar) above their respective melting points to $700{ }^{\circ} \mathrm{C}$ under inert atmosphere. After $5 \mathrm{~min}$ at $700{ }^{\circ} \mathrm{C}$ the material was cooled naturally to room temperature and the resulting product was ground using a mortar and pestle.

\section{Assembly and testing of half- and full-cells}

The following battery components were used: carbon black (CB, Super C65, TIMCAL), carboxymethylcellulose (CMC, Grade: 2200, Daicel Fine Chem. Ltd.), $\mathrm{NaClO}_{4}$ (98\%, Alfa Aesar, additionally dried), propylene carbonate (PC, BASF, battery grade), fluoroethylene carbonate (FEC, Solvay, battery grade), $1 \mathrm{M} \mathrm{LiPF}_{6}$ in a mixture of ethyl carbonate and dimethyl carbonate (EC : DMC, $1: 1$, Merck, battery grade), glass microfiber separator (GF/D, Whatman), and $\mathrm{Cu}$ foil ( $9 \mu \mathrm{m}$ thick, MTI Corporation). SnSb-containing electrodes were prepared by mixing SnSb (NCs or bulk), CB and CMC (64\% : 21\%: 15\%) with water using a Fritsch Pulverisette 7 classic planetary mill (500 rpm, 1 hour). The resulting slurries were coated onto $\mathrm{Cu}$ foil and dried at $80{ }^{\circ} \mathrm{C}$ for $12 \mathrm{~h}$ under vacuum. The final loading was $\sim 0.5 \mathrm{mg}$ $\mathrm{cm}^{-2}$. Electrochemical measurements were conducted in airtight coin-type cells assembled in an Ar-filled glovebox $\left(\mathrm{O}_{2}<\right.$ $\left.0.1 \mathrm{ppm}, \mathrm{H}_{2} \mathrm{O}<0.1 \mathrm{ppm}\right)$. Elemental lithium and sodium were employed as both the reference and counter electrode in half-cells. $\mathrm{LiCoO}_{2}$ (MTI Corporation) coated onto Al foil was used as the Li-ion cathode for full-cells (the loading of active material was $\sim 20 \mathrm{mg} \mathrm{cm}^{-2}$ ). For Na-ion full-cell experiments, $\mathrm{Na}_{1.5} \mathrm{VPO}_{4.8} \mathrm{~F}_{0.7}$ was prepared according to Park et al. ${ }^{45}$ as the cathode. Prior to electrode preparation, $\mathrm{Na}_{1.5} \mathrm{VPO}_{4.8} \mathrm{~F}_{0.7}$ was carbon-coated by ball-milling with $\mathrm{CB}(20 \mathrm{wt} \%)$ and annealing at $450{ }^{\circ} \mathrm{C}$ for $12 \mathrm{~h} .{ }^{46}$ Before the assembly of Na-ion full-cells, $\mathrm{SnSb}$ electrodes were charged/discharged for 5 cycles $v s$. elemental $\mathrm{Na}$ in the potential range of 0.005-2.0 $\mathrm{V}$ at a current of $200 \mathrm{~mA} \mathrm{~g}^{-1}$. As the electrolyte, $1 \mathrm{M} \mathrm{LiPF}_{6}$ in EC : DMC with $3 \%$ FEC was used for LIBs and $1 \mathrm{M} \mathrm{NaClO}_{4}$ in PC with $10 \%$ FEC was used for SIBs in this work. One layer of glass microfiber served as the separator in all cases. Galvanostatic cycling experiments were carried out at room temperature on an MPG2 multichannel workstation (BioLogic). For Li-ion full-cell experiments, the batteries were cycled in the potential range of 2.0-3.9 $\mathrm{V}$ at a current of $400 \mathrm{~mA} \mathrm{~g}^{-1}$. Na-ion full-cell experiments were conducted within a limited charge and discharge capacity window of $400 \mathrm{~mA} \mathrm{~h} \mathrm{~g}^{-1}$, in the potential range of 1.5-4.3 $\mathrm{V}$ at a current density of $200 \mathrm{~mA} \mathrm{~g}^{-1}$. All capacities reported in this work correspond to the content of SnSb.

\section{Materials characterization}

Transmission electron microscopy (TEM) images were obtained using a Philips CM30 microscope operating at $300 \mathrm{kV}$ using carbon-coated $\mathrm{Cu}$ grids as substrates (Ted-Pella). Powder X-ray diffraction (XRD) was performed on a STOE STADI P diffractometer ( $\mathrm{Cu}-\mathrm{K} \alpha_{1}$ irradiation). Scanning electron microscopy (SEM) and energy-dispersive X-ray spectroscopy (EDX) measurements were carried out using a NanoSEM 230 microscope.

\section{Results and discussion}

In the novel synthesis route to SnSb NCs (Fig. 1) developed herein, a solution of $\mathrm{NaBH}_{4}$ in 1-methyl-2-pyrrolidone (NMP) was heated under nitrogen to $60{ }^{\circ} \mathrm{C}$, followed by the consecutive injections of $\mathrm{SnCl}_{2}$ and then $\mathrm{SbCl}_{3}$ dissolved in the same solvent. As in our previously reported "expensive" organometallic synthesis of $\mathrm{SnSb} \mathrm{NCs,}{ }^{40} \mathrm{Sb}$ is introduced last to prevent the formation of Sb NCs. As seen in TEM images (Fig. 1b) the resulting SnSb NCs have a size distribution between 10 and 30 nm. XRD measurements confirm that the sole crystalline 
a

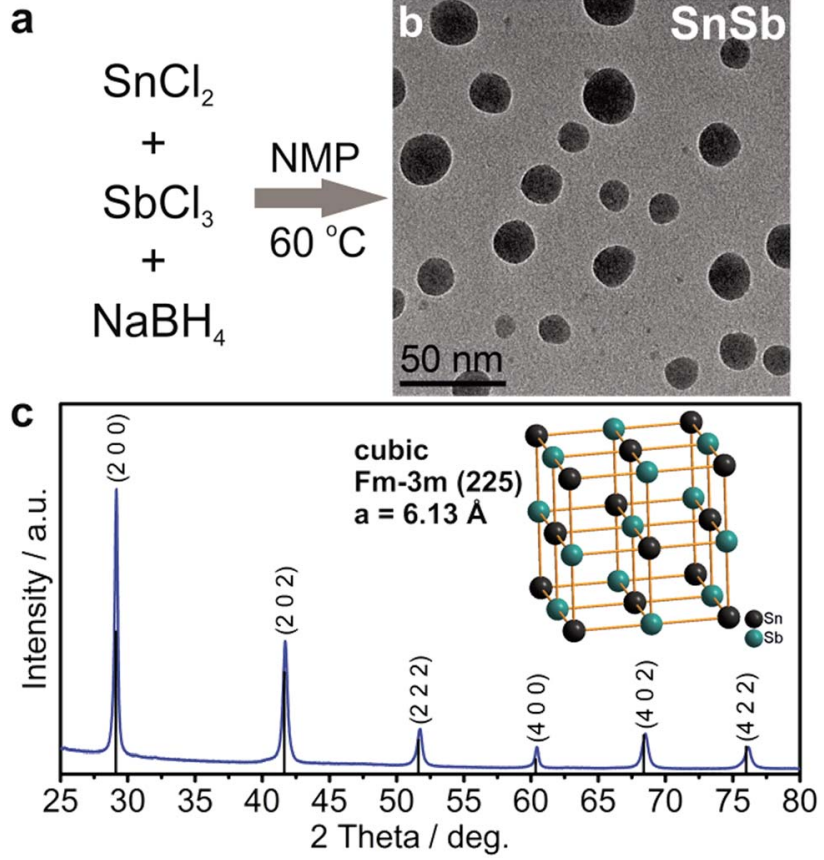

Fig. 1 Synthesis and characterization of SnSb NCs. (a) Reaction scheme. (b) Transmission electron microscopy (TEM) image. (c) X-ray diffraction (XRD) pattern of SnSb NCs, indexed as cubic SnSb (COD entry 9008724).

product is a cubic SnSb compound (space group $F m \overline{3} m$ (225), $a=6.13 \AA$, COD entry 9008724), without any traces of Sn, $\mathrm{Sb}$ or their respective oxides (Fig. 1c). Notably, even for storage of eight months under ambient conditions no formation of crystalline oxides can be detected (Fig. S1 $\dagger$ ). Efficient removal of the main side product $\mathrm{NaCl}$ and potentially unreacted $\mathrm{NaBH}_{4}$, $\mathrm{SnCl}_{2}$ or $\mathrm{SbCl}_{3}$ is further evidenced by the absence of signals corresponding to sodium and chlorine in the energy dispersive X-ray (EDX) spectra of the purified SnSb NCs (Fig. S2 $\dagger$ ). Together, the use of inexpensive reagents, absence of surfactants, recycling of the solvent (NMP), high reaction yield and the non-essentiality of purification of the final product with organic solvents all lead to the low overall cost of this synthesis of $\leq 0.3$ USD per gram of SnSb (which is essentially only the cost of the starting salts and reducing agent; see also Table S1†). In stark contrast to hydrothermal/solvothermal procedures, ${ }^{47,48}$ the synthesis presented herein is carried out at low temperatures, under ambient pressure and with short, sub-minute reaction times, ideal for up-scaling.

\section{Lithium- and sodium-ion half-cell tests}

Half-cell experiments serve to shed initial light on the capacity, energy density and rate capability of the anodes investigated in this work (Fig. 2). Working electrodes were prepared by mixing the SnSb NCs with carbon black (CB) and carboxymethylcellulose (CMC) as a binder in water and coating the resulting slurry onto $\mathrm{Cu}$ foil (for Li- and Na-ion cells, respectively). In this regard, it should be noted that $\mathrm{SnSb}$ NCs retain their cubic structure after electrode preparation without the formation of
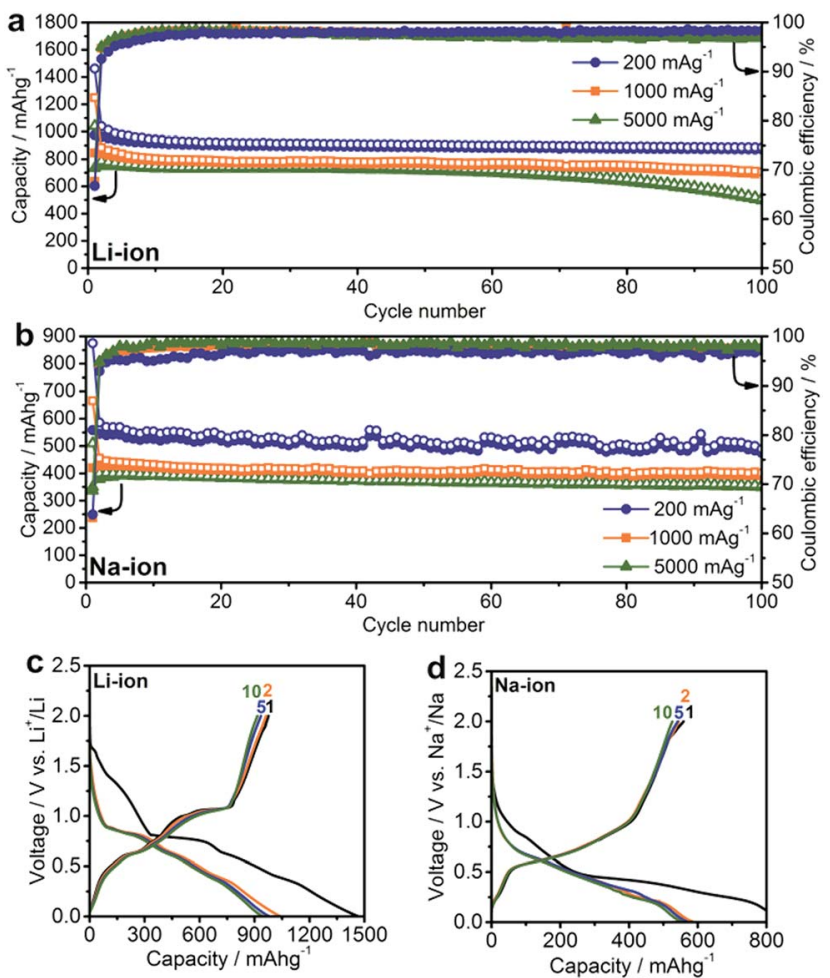

Fig. 2 Electrochemical performance of SnSb NCs. Capacity retention of SnSb NCs in (a) Li-ion and (b) Na-ion half-cells at currents of 200, 1000 and $5000 \mathrm{~mA} \mathrm{~g}^{-1}$. Galvanostatic charge and discharge curves of $\mathrm{SnSb}$ NCs in (c) Li-ion and (d) Na-ion half-cells at a current of $200 \mathrm{~mA}$ $\mathrm{g}^{-1}$. All measurements were performed in the potential range of $0.005-2.0 \mathrm{~V}$.

crystalline oxides (Fig. S1†). Standard liquid electrolyte formulations were used: $\mathrm{LiPF}_{6}$ in EC:DMC for Li-ion and $\mathrm{NaClO}_{4}$ in PC for Na-ion cells. In both cases, FEC was added to the electrolyte because of its known beneficial effect on cycling stability due to the stabilization of the solid-electrolyte interface (SEI). ${ }^{49-52}$

As is apparent in Fig. 2a, SnSb NCs deliver initial capacities close to the theoretical maximum at all tested current densities, with values of 980,850 and $730 \mathrm{~mA} \mathrm{~h} \mathrm{~g}^{-1}$ at 200,1000 , and 5000 $\mathrm{mA} \mathrm{g}^{-1}$, respectively, and retain $90 \%, 80 \%$ and $70 \%$ of these initial capacities after 100 cycles. The observation of capacities that are higher than the theoretical capacity (by up to $10 \%$ ) may arise from a contribution by amorphous carbon of $\sim 100-200$

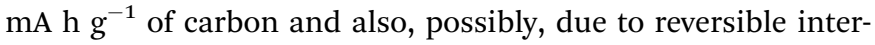
facial lithium storage mechanisms as previously reported for conversion-type materials ${ }^{53,54}$ or even reversible Li-ion storage by a polymeric gel-like layer formed by the electrolyte. ${ }^{55} \mathrm{~A}$ significant irreversible capacity is observed in the first few cycles, resulting in an initial coulombic efficiency of just 63$70 \%$ for both Li-ion and Na-ion cells. This irreversible capacity can be attributed to the formation of an SEI layer over the large surface area of the nanostructured electrode. During subsequent cycles, the coulombic efficiency rises to $\sim 97-98 \%$, indicating that side reactions such as SEI reformation or electrolyte decomposition continue to occur, causing the remaining $2-3 \%$ deficit. 
Despite only a minor difference in theoretical capacity between $\mathrm{Na}_{3} \mathrm{Sb}$ and $\mathrm{Na}_{3.75} \mathrm{Sn}$, significantly lower capacities were observed for $\mathrm{SnSb} \mathrm{NC}$ Na-ion anodes, as in previous reports. ${ }^{\mathbf{4 0 , 5 6}}$ In particular, at currents of 200,1000 and $5000 \mathrm{~mA} \mathrm{~g}^{-1}$, initial capacities of only 560, 420 and $380 \mathrm{~mA} \mathrm{~h} \mathrm{~g}^{-1}$ were obtained, respectively. However, contrary to Li-ion half-cells, a much higher fraction of the initial capacity was retained ( 90-95\%) after 100 cycles at these current densities. This result is clearly an improvement over previous reports of $\mathrm{Na}$-ion storage in $\mathrm{SnSb}$ (for a detailed comparison with existing literature reports, see Tables S2 and S3†). ${ }^{\mathbf{1 8 3 8 , 4 0 - 4 4 , 5 2 , 5 6 - 6 0}}$ The small size of SnSb NCs enhances the kinetics of the charge/discharge reactions due to fast ionic and electronic transport, and also leads to improved cycling stability by more effectively accommodating the impact of volume changes during cycling. ${ }^{26,31}$ The importance of downsizing of the active material is further evidenced by comparison with electrochemical experiments using micrometer-sized SnSb particles, prepared by melting elemental Sn and Sb powders (Fig. $\mathrm{S} 3 \dagger$ ). Such bulk SnSb particles show much poorer capacity retention for both Li- and Naion half-cells (Fig. S4†), despite similar reaction mechanisms as indicated by the similarities of the charge/discharge curves (Fig. S5 $\dagger$ ). Notably, compared to monodisperse $20 \mathrm{~nm}$ particles, ${ }^{40}$ the herein presented SnSb NCs, show the same or even better electrochemical performance, indicating that narrow size distributions are not crucial for obtaining good electrochemical performance. Moreover, the absence of any surfactants during the reaction most likely leads to higher capacity levels compared to monodisperse $20 \mathrm{~nm} \mathrm{SnSb} \mathrm{NCs,} \mathrm{since} \mathrm{the}$ remaining insulating ligands on the surface can decrease the storage capacity. Apart from their high storage capacities, $\mathrm{SnSb}$ NCs show relatively low delithiation and desodiation potentials (Fig. 2c and d), making them highly attractive materials for fullcell applications. It should also be noted that for Li-ion storage the galvanostatic charge/discharge curves are essentially comprised of a combination of the features of the pure phase compounds (the delithiation of Sn occurring between 0.8 and $0.4 \mathrm{~V}$ and $\mathrm{Sb}$ at $\sim 1.1 \mathrm{~V}$ ) whereas the alloying reaction of $\mathrm{SnSb}$ NCs with $\mathrm{Na}$ is clearly different. ${ }^{19}$ The same conclusion can be made from cyclic voltammetry measurements, which are fully consistent with previous reports on $\mathrm{SnSb}$ (Fig. 3).$^{38,52}$

The reaction mechanism of $\mathrm{SnSb}$ with $\mathrm{Na}$ is not fully clarified due to difficulties to analyze the amorphous intermediates and
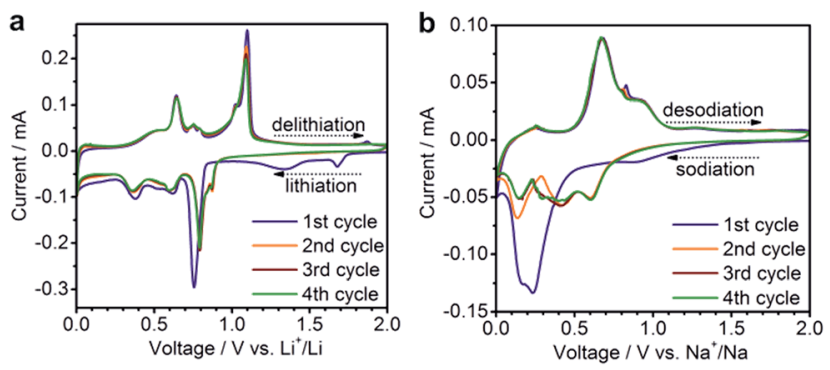

Fig. 3 Cyclic voltammograms of SnSb NCs tested in (a) Li-ion or (b) $\mathrm{Na}$-ion half-cells using a scan rate of $0.1 \mathrm{mV} \mathrm{s}^{-1}$ in the potential range of $0.005-2.0 \mathrm{~V}$. products, ${ }^{61}$ whereas the reaction mechanism of $\mathrm{Sb}$ has been elucidated to proceed via the following steps (where c - crystalline, a - amorphous): ${ }^{62}$

$1^{\text {st }}$ sodiation: $\mathrm{c}-\mathrm{Sb} \rightarrow \mathrm{a}-\mathrm{Na}_{3-x} \mathrm{Sb}+\mathrm{c}-\mathrm{Na}_{3-x} \mathrm{Sb} \rightarrow \mathrm{c}-\mathrm{Na}_{3-x} \mathrm{Sb}$

$1^{\text {st }}$ desodiation: $\mathrm{c}-\mathrm{Na}_{3-x} \mathrm{Sb} \rightarrow \mathrm{a}-\mathrm{Na}_{1.7} \mathrm{Sb} \rightarrow \mathrm{a}-\mathrm{Na}_{1.0} \mathrm{Sb} \rightarrow$ $\mathrm{a}-\mathrm{Na}_{1.0} \mathrm{Sb}+\mathrm{c}-\mathrm{Sb}$

$2^{\text {nd }}$ sodiation: $\mathrm{a}-\mathrm{Na}_{1.0} \mathrm{Sb}+\mathrm{c}-\mathrm{Sb} \rightarrow \mathrm{a}-\mathrm{Na}_{1.7} \mathrm{Sb}+\mathrm{c}-\mathrm{Sb} \rightarrow \mathrm{a}-\mathrm{Na}_{1.7} \mathrm{Sb}$

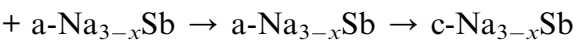

Transition through amorphous phases, helping in mitigating volumetric changes, has been hypothesized as one of the reasons for the relatively high cycling stability of Sb-based electrodes. $^{62}$ In the case of $\mathrm{Sn}$, the sodiation mechanism was proposed to take place according to the following sequence: ${ }^{63}$

$$
\mathrm{c}-\mathrm{Sn} \rightarrow \mathrm{c}-\mathrm{NaSn}_{3} \rightarrow \mathrm{a}-\mathrm{NaSn} \rightarrow \mathrm{c}-\mathrm{Na}_{2.25} \mathrm{Sn} \rightarrow \mathrm{c}-\mathrm{Na}_{3.75} \mathrm{Sn}
$$

However, it should be noted that this sequence was obtained at low current rates $(\mathrm{C} / 50)$ with an additional potentiostatic step at $5 \mathrm{mV} v s . \mathrm{Na}^{+} / \mathrm{Na}$. Under more practical cycling conditions, at higher rates, full sodiation of $\mathrm{Sn}$ to $\mathrm{Na}_{3.75} \mathrm{Sn}$ might in fact not occur, ${ }^{64}$ as supported by significantly lower capacities for $\mathrm{Sn}$ based electrodes. ${ }^{65-67}$ Notably, in the case of $\mathrm{SnSb}$ electrodes $\mathrm{Na}_{3} \mathrm{Sb}$ could be crystallized at elevated temperatures, whereas Sn environments remain incompletely sodiated, as reported by Baggetto et al. ${ }^{61}$ Thus, the generally lower capacity of SnSbbased anodes for Na-ion storage compared to Li-ion storage $^{\mathbf{4 0 , 5 6}}$ - which is also observed for the herein presented SnSb NCs - might be attributed to not fully sodiated Sn-phases.

\section{Lithium- and sodium-ion full-cell tests}

To evaluate the practical utility of $\mathrm{SnSb}$ nanomaterials as anodes, Li- and Na-ion full-cells were assembled using standard cathode materials (Fig. 4). Anode-limited operation of a full-cell allows the assessment of the behavior of the anode under more practically relevant conditions. As in half-cell experiments, all specific currents and capacities correspond to the mass of the $\mathrm{SnSb}$ active material in the anode.

Li-ion full-cells were assembled using commercial $\mathrm{LiCoO}_{2}$ cathodes and then cycled in the potential range of 2.0-3.9 V with a current density of $400 \mathrm{~mA} \mathrm{~g}^{-1}$ (related to the anode). For at least 60 cycles, $\mathrm{SnSb}$ NCs deliver an average Li-ion storage capacity of $600 \mathrm{~mA} \mathrm{~h} \mathrm{~g}^{-1}$ (Fig. 4a) with an average discharge voltage of $3.0 \mathrm{~V}$.

$\mathrm{Na}$-ion full-cells were assembled using $\mathrm{Na}_{1.5} \mathrm{VPO}_{4.8} \mathrm{~F}_{0.7}$ as the cathode, synthesized according to Park et al. ${ }^{\mathbf{4 5}}$ and characterized by powder XRD (Fig. S6†). This cathode material exhibits high cycling stability and a high sodiation potential $(\sim 3.8 \mathrm{~V} v s$. $\mathrm{Na}^{+} / \mathrm{Na}$, Fig. S7 $\left.\dagger\right) .{ }^{45}$ Prior to full-cell experiments, $\mathrm{SnSb}$ anodes were cycled $v s$. elemental $\mathrm{Na}$ at a current of $200 \mathrm{~mA} \mathrm{~g}^{-1}$ in the potential range of $0.005-2.0 \mathrm{~V}$ for 5 cycles in order to form a stable SEI layer and therefore minimize the charge loss during subsequent cycles. Both charge and discharge capacities were limited to $400 \mathrm{~mA} \mathrm{~h} \mathrm{~g}^{-1}$ within the potential range of $4.3-1.5 \mathrm{~V}$ 

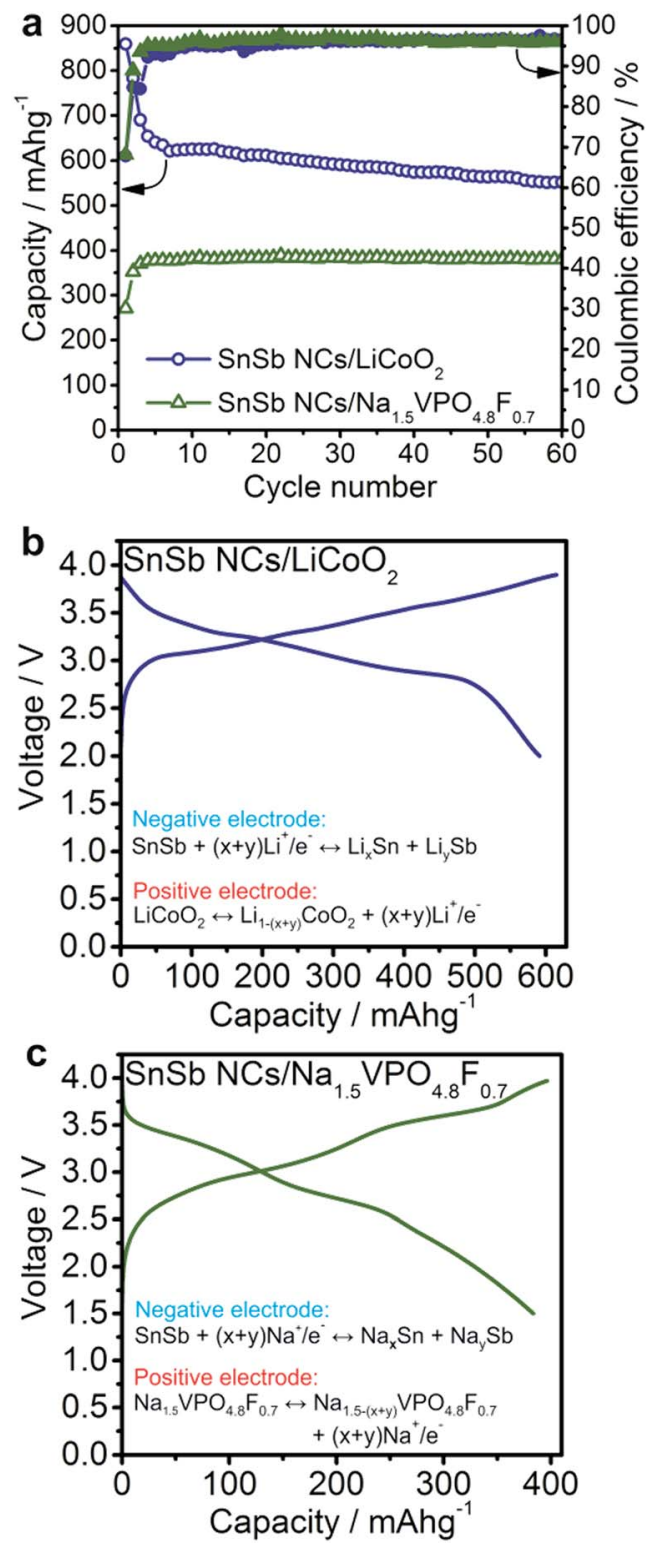

Fig. 4 Electrochemical performance of $\mathrm{SnSb}$ NCs in lithium-ion and sodium ion full-cells using $\mathrm{LiCoO}_{2}$ and $\mathrm{Na}_{1.5} \mathrm{VPO}_{4.8} \mathrm{~F}_{0.7}$ as the cathode materials, respectively. (a) Capacity retention of SnSb NCs at a current of $400 \mathrm{~mA} \mathrm{~g}^{-1}$ in Li-ion and at $200 \mathrm{~mA} \mathrm{~g}^{-1}$ in $\mathrm{Na}$-ion full cells. Li-ion cells were cycled in the potential range of $2.0-3.9 \mathrm{~V}$. Na-ion cells were cycled with a limitation of the charge and discharge capacity to 400 $\mathrm{mA} \mathrm{h} \mathrm{g}^{-1}$. Galvanostatic charge/discharge curves of the (b) Li-ion and (c) Na-ion full-cells, during the $30^{\text {th }}$ cycle (see also Fig. $58 \dagger$ ). The displayed specific capacities and currents correspond to the mass of SnSb NCs.

and the cells were cycled at a current of $200 \mathrm{~mA} \mathrm{~g}^{-1}$. As can be seen in Fig. 4, the SnSb/ $\mathrm{Na}_{1.5} \mathrm{VPO}_{4.8} \mathrm{~F}_{0.7} \mathrm{Na}$-ion full-cell delivers a stable capacity of $\sim 400 \mathrm{~mA} \mathrm{~h} \mathrm{~g}^{-1}$ for at least 60 cycles, with an average discharge voltage of $2.7 \mathrm{~V}$ (Fig. S8 $\dagger$ ).

Based on the anodic capacities obtained for $\mathrm{Li}$ - and $\mathrm{Na}$-ion fullcells and the theoretical capacities of the cathode materials $\left(140 \mathrm{~mA} \mathrm{~h} \mathrm{~g}^{-1} \text { for } \mathrm{LiCoO}_{2} \text { and } 129.7 \mathrm{~mA} \mathrm{~h} \mathrm{~g}^{-1} \text { for } \mathrm{Na}_{1.5} \mathrm{VPO}_{4.8} \mathrm{~F}_{0.7}\right)^{45}$ the theoretical cell capacities can be estimated, using $C_{\text {cell }}=$
$C_{\text {anode }} C_{\text {cathode }} /\left(C_{\text {anode }}+C_{\text {cathode }}\right)$. This cell capacity multiplied by the average discharge voltage yields the theoretical energy density of the cell. In this way, the energy density of the $\mathrm{SnSb} / \mathrm{Na}_{1.5} \mathrm{VPO}_{4.8} \mathrm{~F}_{0.7}$ full-cell battery developed in this work compares favorably to other recently reported Na-ion full-cells. ${ }^{68-71}$ Similarly, the $\mathrm{SnSb} / \mathrm{LiCoO}_{2}$ Li-ion full-cell exhibits an energy density of $340 \mathrm{~W} \mathrm{~h} \mathrm{~kg}{ }^{-1}$, comparable to the graphite/ $\mathrm{LiCoO}_{2}$ system. One possible advantage of SnSb over graphite lies in its three-fold higher density compared to graphite $\left(6.9 \mathrm{~g} \mathrm{~cm}^{-3} v s\right.$. $2.2 \mathrm{~g} \mathrm{~cm}^{-3}$, respectively). This potentially enables higher volumetric energy densities by up to $30 \%: 1796 \mathrm{~W} \mathrm{~h} \mathrm{~L}^{-1}$ for the $\mathrm{SnSb} /$ $\mathrm{LiCoO}_{2}$ full-cell compared to $1339 \mathrm{~W} \mathrm{~h} \mathrm{~L}^{-1}$ for graphite/LiCoO${ }_{2}$, assuming a density of $5 \mathrm{~g} \mathrm{~cm}^{-3}$ for $\mathrm{LiCoO}_{2}{ }^{72}$

\section{Conclusions}

In summary, we report an inexpensive and scalable synthesis of SnSb nanocrystals of 10-30 $\mathrm{nm}$ in size using metal chlorides as precursors and sodium borohydride as a reducing agent. The important advantages of this method over previous solution syntheses are its nearly quantitative reaction yield and its avoidance of the use of surfactants. The resulting NCs can thus be isolated simply by centrifugation or filtering, and purified by rinsing with water. Lithium-ion storage in such SnSb NCs is characterized by capacities close to the theoretical maximum, with an average value of $760 \mathrm{~mA} \mathrm{~h} \mathrm{~g}{ }^{-1}$ for 100 cycles at a high current density of $1000 \mathrm{~mA} \mathrm{~g}^{-1}$. For sodium-ion storage, lower capacities are obtained, but with higher relative capacity retention upon cycling. The first results from Li-ion and Na-ion full-cell experiments, using $\mathrm{LiCoO}_{2}$ and $\mathrm{Na}_{1.5} \mathrm{VPO}_{4.8} \mathrm{~F}_{0.7}$ as the cathodes, indicate stable cycling performance of SnSb NCs with specific Li- and Na-ion anodic capacities (average discharge voltage in parentheses) of $600 \mathrm{~mA} \mathrm{~h} \mathrm{~g}^{-1}(3.0 \mathrm{~V})$ and $400 \mathrm{~mA} \mathrm{~h} \mathrm{~g}^{-1}$ $(2.7 \mathrm{~V})$, respectively.

\section{Acknowledgements}

This work was financially supported by the Swiss Federal Commission for Technology and Innovation (CTI, Project Nr. 14698.2 PFIW-IW), CTI Swiss Competence Centers for Energy Research (SCCER, "Heat and Electricity Storage"), ETH Zürich (Grant Nr. ETH-56 12-2), Competence Center for Energy and Mobility (CCEM, project SLIB) and by Belenos Clean Power Holding. Electron microscopy was performed at the Empa Electron Microscopy Center. We thank Dr Nicholas Stadie for reading the manuscript.

\section{Notes and references}

1 R. Van Noorden, Nature, 2014, 507, 26-28.

2 D. Larcher and J. M. Tarascon, Nat. Chem., 2015, 7, 19-29.

3 V. Palomares, P. Serras, I. Villaluenga, K. B. Hueso, J. Carretero-Gonzalez and T. Rojo, Energy Environ. Sci., 2012, 5, 5884-5901.

4 M. D. Slater, D. Kim, E. Lee and C. S. Johnson, Adv. Funct. Mater., 2013, 23, 947-958. 
5 H. Pan, Y.-S. Hu and L. Chen, Energy Environ. Sci., 2013, 6, 2338-2360.

6 P. Ge, Solid State Ionics, 1988, 28-30, 1172-1175.

7 S. Komaba, Y. Matsuura, T. Ishikawa, N. Yabuuchi, W. Murata and S. Kuze, Electrochem. Commun., 2012, 21, 65-68.

8 Y. Wen, K. He, Y. Zhu, F. Han, Y. Xu, I. Matsuda, Y. Ishii, J. Cumings and C. Wang, Nat. Commun., 2014, 5, 4033.

9 L. M. Wu, D. Buchholz, D. Bresser, L. G. Chagas and S. Passerini, J. Power Sources, 2014, 251, 379-385.

10 D. Y. Yu, P. V. Prikhodchenko, C. W. Mason, S. K. Batabyal, J. Gun, S. Sladkevich, A. G. Medvedev and O. Lev, Nat. Commun., 2013, 4, 2922.

11 Y. Wang, X. Yu, S. Xu, J. Bai, R. Xiao, Y. S. Hu, H. Li, X. Q. Yang, L. Chen and X. Huang, Nat. Commun., 2013, 4, 2365.

12 Y. Sun, L. Zhao, H. Pan, X. Lu, L. Gu, Y. S. Hu, H. Li, M. Armand, Y. Ikuhara, L. Chen and X. Huang, Nat. Commun., 2013, 4, 1870.

13 Y. M. Lin, P. R. Abel, A. Gupta, J. B. Goodenough, A. Heller and C. B. Mullins, ACS Appl. Mater. Interfaces, 2013, 5, 8273-8277.

14 J. Qian, X. Wu, Y. Cao, X. Ai and H. Yang, Angew. Chem., Int. Ed., 2013, 52, 4633-4636.

15 Y. Kim, Y. Park, A. Choi, N.-S. Choi, J. Kim, J. Lee, J. H. Ryu, S. M. Oh and K. T. Lee, Adv. Mater., 2013, 25, 3045-3049.

16 N. Yabuuchi, Y. Matsuura, T. Ishikawa, S. Kuze, J.-Y. Son, Y.-T. Cui, H. Oji and S. Komaba, ChemElectroChem, 2014, 1, 580-589.

17 W.-J. Li, S.-L. Chou, J.-Z. Wang, H.-K. Liu and S.-X. Dou, Nano Lett., 2013, 13, 5480-5484.

18 L. Xiao, Y. Cao, J. Xiao, W. Wang, L. Kovarik, Z. Nie and J. Liu, Chem. Commun., 2012, 48, 3321-3323.

19 A. Darwiche, M. T. Sougrati, B. Fraisse, L. Stievano and L. Monconduit, Electrochem. Commun., 2013, 32, 18-21.

20 Y. Zhu, X. Han, Y. Xu, Y. Liu, S. Zheng, K. Xu, L. Hu and C. Wang, ACS Nano, 2013, 7, 6378-6386.

21 X. Zhou, Z. Dai, J. Bao and Y.-G. Guo, J. Mater. Chem. A, 2013, 1, 13727-13731.

22 D. H. Nam, K. S. Hong, S. J. Lim and H. S. Kwon, J. Power Sources, 2014, 247, 423-427.

23 L. Wu, X. Hu, J. Qian, F. Pei, F. Wu, R. Mao, X. Ai, H. Yang and Y. Cao, Energy Environ. Sci., 2014, 7, 323-328.

24 B. Farbod, K. Cui, W. P. Kalisvaart, M. Kupsta, B. Zahiri, A. Kohandehghan, E. M. Lotfabad, Z. Li, E. J. Luber and D. Mitlin, ACS Nano, 2014, 8, 4415-4429.

25 C. Nithya and S. Gopukumar, J. Mater. Chem. A, 2014, 2, 10516-10525.

26 P. G. Bruce, B. Scrosati and J.-M. Tarascon, Angew. Chem., Int. Ed., 2008, 47, 2930-2946.

27 M. R. Palacin, Chem. Soc. Rev., 2009, 38, 2565-2575.

28 A. Magasinski, P. Dixon, B. Hertzberg, A. Kvit, J. Ayala and G. Yushin, Nat. Mater., 2010, 9, 353-358.

29 C. K. Chan, R. N. Patel, M. J. O'Connell, B. A. Korgel and Y. Cui, ACS Nano, 2010, 4, 1443-1450.
30 K. Kravchyk, L. Protesescu, M. I. Bodnarchuk, F. Krumeich, M. Yarema, M. Walter, C. Guntlin and M. V. Kovalenko, J. Am. Chem. Soc., 2013, 135, 4199-4202.

31 M. F. Oszajca, M. I. Bodnarchuk and M. V. Kovalenko, Chem. Mater., 2014, 26, 5422-5432.

32 N. Liu, Z. Lu, J. Zhao, M. T. McDowell, H.-W. Lee, W. Zhao and Y. Cui, Nat. Nanotechnol., 2014, 9, 187-192.

33 A. Jahel, C. M. Ghimbeu, L. Monconduit and C. Vix-Guterl, Adv. Energy Mater., 2014, 4, 1400025.

34 J. Liu, Y. Wen, P. A. van Aken, J. Maier and Y. Yu, Nano Lett., 2014, 14, 6387-6392.

35 H. Chen, C. Wang, W. Dong, W. Lu, Z. Du and L. Chen, Nano Lett., 2015, 15, 798-802.

36 M. Walter, R. Erni and M. V. Kovalenko, Sci. Rep., 2015, 5, 8418.

37 Y. Zhu, Y. Wen, X. Fan, T. Gao, F. Han, C. Luo, S.-C. Liou and C. Wang, ACS Nano, 2015, 9, 3254-3264.

38 S. Fan, T. Sun, X. Rui, Q. Yan and H. H. Hng, J. Power Sources, 2012, 201, 288-293.

39 A. Darwiche, M. T. Sougrati, B. Fraisse, L. Stievano and L. Monconduit, Electrochem. Commun., 2013, 32, 18-21.

40 M. He, M. Walter, K. V. Kravchyk, R. Erni, R. Widmer and M. V. Kovalenko, Nanoscale, 2015, 7, 455-459.

41 Y. Wang and J. Y. Lee, Angew. Chem., Int. Ed., 2006, 45, 70397042.

42 L. Fan, J. Zhang, Y. Zhu, X. Zhu, J. Liang, L. Wang and Y. Qian, RSC Adv., 2014, 4, 62301-62307.

43 D. Sun, B. An, B. Zhang, Q. Ru, X. Hou and S. Hu, J. Solid State Electrochem., 2014, 18, 2573-2579.

44 J. Li, Q. Ru, S. Hu, D. Sun, B. Zhang and X. Hou, Electrochim. Acta, 2013, 113, 505-513.

45 Y.-U. Park, D.-H. Seo, H.-S. Kwon, B. Kim, J. Kim, H. Kim, I. Kim, H.-I. Yoo and K. Kang, J. Am. Chem. Soc., 2013, 135, 13870-13878.

46 Y.-U. Park, D.-H. Seo, B. Kim, K.-P. Hong, H. Kim, S. Lee, R. A. Shakoor, K. Miyasaka, J.-M. Tarascon and K. Kang, Sci. Rep., 2012, 2, 704.

47 J. Xie, W. Song, Y. Zheng, S. Liu, T. Zhu, G. Cao and X. Zhao, Int. J. Smart Nano Mater., 2011, 2, 261-271.

48 L. Li, K. Seng, D. Li, Y. Xia, H. Liu and Z. Guo, Nano Res., 2014, 7, 1466-1476.

49 V. Etacheri, O. Haik, Y. Goffer, G. A. Roberts, I. C. Stefan, R. Fasching and D. Aurbach, Langmuir, 2011, 28, 965-976.

50 S. Komaba, T. Ishikawa, N. Yabuuchi, W. Murata, A. Ito and Y. Ohsawa, ACS Appl. Mater. Interfaces, 2011, 3, 4165-4168.

51 A. M. Chockla, K. C. Klavetter, C. B. Mullins and B. A. Korgel, Chem. Mater., 2012, 24, 3738-3745.

52 L. Ji, M. Gu, Y. Shao, X. Li, M. H. Engelhard, B. W. Arey, W. Wang, Z. Nie, J. Xiao, C. Wang, J.-G. Zhang and J. Liu, Adv. Mater., 2014, 26, 2901-2908.

53 Y. F. Zhukovskii, P. Balaya, E. A. Kotomin and J. Maier, Phys. Rev. Lett., 2006, 96, 058302.

54 Y.-Y. Hu, Z. Liu, K.-W. Nam, O. J. Borkiewicz, J. Cheng, X. Hua, M. T. Dunstan, X. Yu, K. M. Wiaderek, L.-S. Du, K. W. Chapman, P. J. Chupas, X.-Q. Yang and C. P. Grey, Nat. Mater., 2013, 12, 1130-1136. 
55 S. Laruelle, S. Grugeon, P. Poizot, M. Dollé, L. Dupont and J.-M. Tarascon, J. Electrochem. Soc., 2002, 149, A627-A634.

56 J.-C. Kim and D.-W. Kim, Electrochem. Commun., 2014, 46, 124-127.

57 M.-S. Park, S. A. Needham, G.-X. Wang, Y.-M. Kang, J.-S. Park, S.-X. Dou and H.-K. Liu, Chem. Mater., 2007, 19, 2406-2410.

58 S. Chen, P. Chen, M. Wu, D. Pan and Y. Wang, Electrochem. Commun., 2010, 12, 1302-1306.

59 R. Yang, J. Huang, W. Zhao, W. Lai, X. Zhang, J. Zheng and X. Li, J. Power Sources, 2010, 195, 6811-6816.

60 X. Niu, H. Zhou, Z. Li, X. Shan and X. Xia, J. Alloys Compd., 2015, 620, 308-314.

61 L. Baggetto, H.-Y. Hah, J.-C. Jumas, C. E. Johnson, J. A. Johnson, J. K. Keum, C. A. Bridges and G. M. Veith, J. Power Sources, 2014, 267, 329-336.

62 P. K. Allan, J. M. Griffin, A. Darwiche, O. J. Borkiewicz, K. M. Wiaderek, K. W. Chapman, A. J. Morris, P. J. Chupas, L. Monconduit and C. P. Grey, J. Am. Chem. Soc., 2016, 138, 2352-2365.

63 L. D. Ellis, T. D. Hatchard and M. N. Obrovac, J. Electrochem. Soc., 2012, 159, A1801-A1805.
64 Z. Li, J. Ding and D. Mitlin, Acc. Chem. Res., 2015, 48, 16571665.

65 M. K. Datta, R. Epur, P. Saha, K. Kadakia, S. K. Park and P. N. Kumta, J. Power Sources, 2013, 225, 316-322.

66 Y. Xu, Y. Zhu, Y. Liu and C. Wang, Adv. Energy Mater., 2013, 3, 128-133.

67 H. Zhu, Z. Jia, Y. Chen, N. Weadock, J. Wan, O. Vaaland, X. Han, T. Li and L. Hu, Nano Lett., 2013, 13, 3093-3100.

68 P. R. Kumar, Y. H. Jung, K. K. Bharathi, C. H. Lim and D. K. Kim, Electrochim. Acta, 2014, 146, 503-510.

69 S.-M. Oh, S.-T. Myung, C. S. Yoon, J. Lu, J. Hassoun, B. Scrosati, K. Amine and Y.-K. Sun, Nano Lett., 2014, 14, 1620-1626.

70 S. Guo, H. Yu, P. Liu, Y. Ren, T. Zhang, M. Chen, M. Ishida and H. Zhou, Energy Environ. Sci., 2015, 8, 1237-1244.

71 J. Ming, H. Ming, W. Yang, W.-J. Kwak, J.-B. Park, J. Zheng and Y.-K. Sun, RSC Adv., 2015, 5, 8793-8800.

72 Y.-C. Lu, B. M. Gallant, D. G. Kwabi, J. R. Harding, R. R. Mitchell, M. S. Whittingham and Y. Shao-Horn, Energy Environ. Sci., 2013, 6, 750-768. 